\title{
Students' and Teacher's Belief About Their Classroom Interactions Toward Teaching and Learning English
}

\section{Martira Fifrilya Ningtyas, Dewi Rochsantiningsih, Handoko Pudjobroto}

\author{
English Education Department \\ Teacher Training and Education Faculty \\ Sebelas Maret University of Surakarta
}

\author{
Email: martira_59@yahoo.co.id
}

\begin{abstract}
Belief is an underlying case in human's decision and attitude, including in the classroom interaction context. Its existence in classroom interaction is revealed in this article by identifying and describing the students' and teacher's belief about their classroom interaction toward teaching and learning English. The study was carried out using qualitative case study in Surakarta, at eighth grades student and their English teacher. The data were collected through questionnaire, interview, classroom observation, and teacher's lesson plan which then reduced to find the smallest valuable unit, categorized based on similarity, and compared to find the relation between the categories thus hypothesis is constructed as the answer. The research findings show that: (1) students believe they have good classroom interaction; (2) the teacher believes that interaction is the students' need facilitating media; then (3) the belief has affected the students' paradigm, that now they like English, and has affected the teacher's decision making on her social interaction and her way of teaching. Having positive belief is beneficial to support cooperative teaching and learning process.
\end{abstract}

Keywords: case study, belief, classroom interaction

\section{INTRODUCTION}

Within education, teaching and learning are two familiar terms. Teaching "refers to a social action or series of actions that are constructed as an individual seeks to bring about change within a classroom or school" (Konsik, Beck, Freese, and Samaras, 2005, p. 86). It positions (Dimić, 2012) teacher as one of environmental factors who influences the students' formative process. Moreover "learning still depends on what teachers do daily with students in classrooms" (Cuban, 2009, p. 4). Teacher-student relationships can be said as a specific influential manner, it because it has similar foundational purpose as instructional practices (Walker and Schussler, 2011). How the teacher manages the students' learning problem or interact with them will influence the student's feedback on learning. If the students' difficulties in mastering the material is not solved, not helped, and then be desperate to survive in English class, they will judge that the lesson is difficult. The more they show refusal reaction like: (1) seldom doing the assignment, (2) seldom paying attention to the lesson, (3) reluctant to try finding the answer and (4) not believing with his or her competence. The clearly refusal is coming from their statement that they do not like English language, and vice versa. Those conditions must be anticipated because it can support the student' belief, the belief which has been created from the past experience (Pishghadam, 2011) and which would be greater or stronger when it gets more supporting evidence (Gunawan, 2008).

Gunawan stated that "secara sederhana belief dapat didefinisikan sebagai 
sesuatu yang kita yakini benar [classically belief can be defined as something that we convince as the truth] (2008, p. 28), belief mendasari segala keputusan, pilihan, sikap, tindakan, dan perilaku kita [belief underlies all our decision, choices, attitude, action, and behaviour] (p. 61)." When the students believe that English is difficult, they tend to self-closed, they may reject all information about English from any sources. If the students believe that English is interesting and is a must to know more about it, the student will enjoy learning English. As an influential person towards student's learning, teacher is wished to have positive belief. The teacher's belief is also necessary because it underlies the teacher's decision of a routine teaching activity.

From many causes that makes the students regard English as a difficult lesson, this research focused on the interaction between students and teacher which is found by their beliefs. The research explored students' and teacher's belief about their classroom interaction toward teaching learning English.

Indonesia is a country that uses English as foreign language. It is "treated as an academic subject in the school system and is not widely used outside the classroom" (Peace Corps, 1989, p. 7). Nevertheless, the lesson plan and its application in class still need to pay attention on (Broughton, Brumfit, Flavell, Hill, and Pincas, 2003) the social interaction between teacher and students, the language activity, material used, and the teaching principles underlying. Its impact also works toward the students achievement that categorized into three phases (New South Wales Department for Education and Training, 2004): beginner with limited understanding and production of spoken or written English; intermediate with acquisition of basic communicative in English; and advance with similar confidence and fluency as native speaker. The most visible manner differentiates learner of second language and foreign language is their motivation that tends to be integrative. Learning the language to survive or communicate in English living environment. While foreign language learner tends to be instrumental, (Broughton et al., 2003) learning for operational purposes likes reading English book or having conversation with native speaker.

Motivation has three dimensions (Schmidt, Boraie, and Kassabgy in Oxford, 1996), which become the reason of the students' activeness: affect is about the enjoyment feeling; goal orientation or learning purpose; and expectancy of one's own abilities. Motivation is fluctuated for the possibly effect caused by environment such as the classroom interaction. Quality of teacher-students relationship is the core of emotional support in classroom interaction (Burleson, 2008), and which determents the enjoyable situation. Classroom interaction also covers classroom organization which puts teacher as effective manager (Mackay, 2006), but requires the students' cooperative working to create a supportive teachinglearning environment. The last dimension of classroom interaction is instructional support which informs about (Vosniadou, 2001) appropriate strategies used by teacher to help the students' understanding.

Interaction that happens more than once can be the received view processed into belief proposition (Huber, 2006). The context of this research is students and teacher classroom interaction thus the students received view focused on the teacher activity supported by his or her personality and teaching style. Teacher personality which contributes to the class 
activity is described into five traits; neuroticism is about person's level of emotional instability; extraversion is about person's intensity of interaction; agreeableness is about person's orientation toward others; openness to new experiences; and conscientiousness is about person's level of easygoingness (Thomason, 2011). Then the teacher teaching style tend to be thought as the results of his or her interpretation about teacher's role in classroom; as planner, manager, quality controller, group organizer, facilitator, motivator, empowerer, or team member (Richard and Lockhart, 2007).

The teacher's proposition comes from information of the students: students' personal data and learning style (Graf, Lin, and Kinshuk, 2002; Graf, Lin, Jeffrey, Kinshuk, 2002), also the students' motivation (Bolkan, Goodboy, and Griffin, 2011). It is about how the teacher sees the students, as (William and Burden, 1997) resisters, receptacles, raw material, clients, partners, individual explorers, or democratic explorers. It is about how the teacher sees the students' motivation. Are they intrinsically motivated or needing additional influence of extrinsic motivation. It is also about how the teacher sees the students' behavior and need as the indicator of their learning style (Ballone and Czerniak, 2001). First learning style is concrete learning style, means that the students are active, interested and curious. They like physical involvement with verbal or visual experiences thus various activities are appropriate for them. They do not like routine activity like written work. Second is analytical learning style, independent students who are serious and push themselves hard. They like activity such as solving problem, systematic strides, and following up principle developed by themselves. Third, style which the members prefer a social approach when learning, it is called as communicative learning style. They learn through interaction such as feedback from teacher, discussion either with the teacher or peers, and group task. The last is authority-oriented learning style which closes to traditional classroom. The teacher is an authority figure who will instruct clearly thus the students follow the class activity exactly as the sequential instruction from the teacher. They are dependent students who do not like discussion activity.

\section{RESEARCH METHODS}

This research was carried out in Surakarta, at 32 students in eighth grades and their English teacher. It was conducted using qualitative case study which bounded the object at the purpose of the study (Merriam, 1998). They are students who learn many things from their life environment which possibly constructed as some beliefs. Thus it is possibly easy for them to construct belief about what they have experienced at school. The techniques of data collection were used in this research in the form of questionnaire, interview, observation, and teacher's lesson plan. Questionnaire is a useful way to gather information of someone's belief in large amount and quickly (Richard and Lockhart, 2007). Interview was used as follow up of specific points in order fully explored a phenomenon studied (Adams and Cox, 2008). Observing is the relying of people's gestures, social interactions, and action (Yin, 2011). The teacher lesson plan was used as the additional data. Further, the data were analyzed (Moleong, 2006) through four steps: data reduction; categorization; synthases; and construct hypothesis. It was reduced to find the smallest valuable unit, categorized based on similarity, and 
compared to find the relation among the categories. When the smallest valuable data across categories showed any relation thus hypothesis was constructed.

\section{RESEARCH FINDINGS DISCUSSIONS}

The research of students' and teacher's belief about their classroom interaction did not use direct question like what is your belief about... but it collected information about some propositions to support belief about classroom interaction. The propositions that support students' belief are the teacher's personality and teaching style, meanwhile the teacher's propositions are the students' personality, motivation, and learning style. The result of students' questionnaire about teacher's personality is served in table 1 .

Table 1. Students' Belief about Teacher's Personality

\begin{tabular}{llll}
\hline Teacher's personality & Low & High & Total \\
\hline 1. Neuroticism & $78 \%$ & $22 \%$ & $100 \%$ \\
2. Extraversion & $22 \%$ & $78 \%$ & $100 \%$ \\
3. Agreeableness & $27 \%$ & $73 \%$ & $100 \%$ \\
4. Openness to new experiences & $23 \%$ & $78 \%$ & $100 \%$ \\
5. Conscientiousness & $17 \%$ & $83 \%$ & $99 \%$ \\
\hline
\end{tabular}

The students believe that the teacher has low of neuroticism and high of extraversion, agreeableness, openness to new experience, and conscientiousness. The used data is the majority or which more than $50 \%$ because it shows the dominant appraisal which is strong, while the minority shows the class appraisal that still spread or does not result an agreement yet. The interviewed students explain their teacher low neuroticism by the term "enjoyable" which is represented as something that can make them comfortable. She is "patient" and "not rampageous", it contradicts to their elementary English teacher. The teacher's extraversion is explained from her willingness to give more explanation when students get problem in understanding the lesson. She is sociable person who often help their learning. Proximity is not the only way to show the teacher's conscientiousness. A student said that the teacher ever talked in high tone toward student who could not do the task even did it in no serious condition. Nevertheless after it passed, the teacher became an enjoyable person again. From the students expression that their teacher is an enjoyable person and that they like the teacher a lot reflects a belief in the teacher's high agreeableness and openness to new experience. The teacher's care in helping the students learning shows one of the teaching styles used and there are more styles believed by students based on their experience. Those are presented as in table 2 resulted from the students' questionnaire.

They convince the teacher's teaching style as quality controller, group organizer, facilitator, and team member. A teacher who will not let her students competency decrease, thus she controls their advancement to make sure that they are following the learning process and master the material. It is appropriate with the information given by the students that the teacher did not let the students get lost in their no understanding, she monitored the students comprehension and "gave extra explanation" to students who still not 
understand the material yet. If taking a deeper look, there is a cause and effect relation between the teacher personality and her teaching style. Because of her conscientiousness makes her controls the quality of her students' comprehension and because of her agreeableness and extraversion makes her playing role as facilitator. Her control is not only felt by certain student but also by other student who are part of the class group. A student felt "scolding moment" although it was not intended toward him. Nevertheless he admitted his eighth grades English teacher was more enjoyable than his elementary teacher. Some students stated that they were "so happy" and "like" the teacher, it seems that she became part of them.

Table 2. Students' Belief about The Teacher's Teaching Style

\begin{tabular}{lllllll}
\hline Teacher's teaching style & SD & D & A & SA & Total \\
\hline 1. & Planner & $1 \%$ & $10 \%$ & $46 \%$ & $1 \%$ & $98 \%$ \\
2. & Manager & $27 \%$ & $39 \%$ & $24 \%$ & $10 \%$ & $99 \%$ \\
3. & Quality Controller & $0 \%$ & $3 \%$ & $52 \%$ & $45 \%$ & $100 \%$ \\
4. & Group organizer & $0 \%$ & $3 \%$ & $66 \%$ & $31 \%$ & $99 \%$ \\
5. & Facilitator & $0 \%$ & $1 \%$ & $42 \%$ & $56 \%$ & $99 \%$ \\
6. & Motivator & $0 \%$ & $3 \%$ & $49 \%$ & $48 \%$ & $100 \%$ \\
7. & Empowerer & $14 \%$ & $15 \%$ & $38 \%$ & $33 \%$ & $99 \%$ \\
8. & Team member & $0 \%$ & $5 \%$ & $34 \%$ & $61 \%$ & $100 \%$ \\
\hline SD
\end{tabular}

$\mathrm{SD}=$ Strongly Disagree, $\mathrm{D}=$ Disagree, $\mathrm{A}=$ Agree, $\mathrm{SA}=$ Strongly Agree

As mentioned previously, belief underlies human's decision and attitude, decision and attitude during the class which also will determine the pattern of the interaction. Students' attitude toward the teacher reflects their appraisal about the teacher's personality and teaching style. When they are comfortable, they will create quiet supportive environment. They are unhesitant to participate in class activity. Table 3 is consisted the interaction happened during the class.

Those interactions also reflect the teacher appraisal about the students' personality, motivation, and learning style. The teacher was close to the students and taught them attention fully because she appraised that students can be resisters, clients, partners, and democratic explores. They are motivated creatures with concrete, analytical, communicative or authorityoriented learning style as founded in the teacher's questionnaire result served in table 4.

Her belief about students as resister was built from the class parallelism and background of the students which are "chaotic, broken home," or " the one who left by the father." It is a condition which possibly creates them as students who "talk" a lot, having personal conversation with their friends during the class. They can be categorized as students with external motivation who consider the teacher as the success determining of learning process. Therefore the teacher used "intermezzo" and certain method to teach this type of students. Another students' personality believed by the teacher was coming from the condition which the students were more established. Here the teacher was "possible to use English language" as one of language conversation, and the teacher did not need to check the student's comprehension one by one. She just "look for seconds" and stop or 
give more explaination when there was difficulty. Thing-pair share technique which stimulates the students' activeness through group discussion either with peers or the teacher reflects a belief about students' communicative learning style which requires such those activity.

Table 3. Classroom Interaction

\begin{tabular}{|c|c|}
\hline Domain & Interaction \\
\hline $\begin{array}{ll}\text { 1. } & \text { Emotional } \\
\text { Support }\end{array}$ & 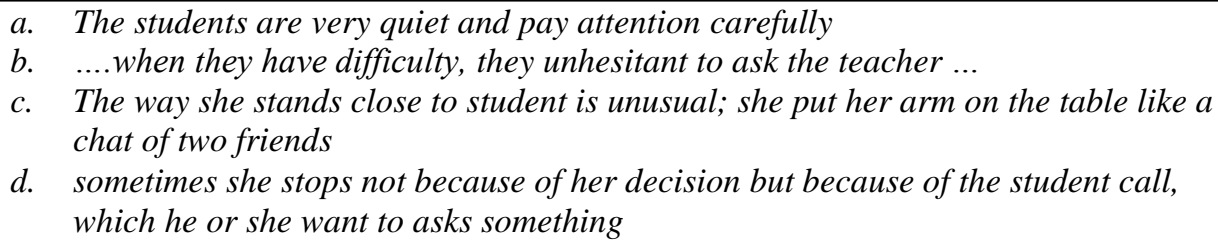 \\
\hline $\begin{array}{ll}\text { 2. } & \text { Classroom } \\
\text { Organization }\end{array}$ & $\begin{array}{l}\text { a. The students are quite and when it is their turn to get involve, they speak up } \\
\text { without doubt or fear } \\
\text { b. Ok for task } 7 \text { please } 10 \text { students come forward and write the answer on the } \\
\text { whiteboard, come on quickly who wants to write the answer } \\
\text { c. The teacher continues turn around the class to check the students work }\end{array}$ \\
\hline $\begin{array}{l}\text { 3. Instructional } \\
\text { Support }\end{array}$ & $\begin{array}{l}\text { a. The students make a note while listen the teacher explanation } \\
\text { b. To make the students more involve in the teaching process, she does drilling, she } \\
\text { mention the subject of the sentence then the students change to be or the verb } \\
\text { c. When the students are brave to answer her question she gives a respond of "iya" } \\
\text { then followed by repetition and additional explanation }\end{array}$ \\
\hline
\end{tabular}

Table 4. Teacher's Questionnaire Result

\begin{tabular}{|c|c|c|c|c|c|c|}
\hline & & SD & $\mathrm{D}$ & A & SA & Total \\
\hline \multirow[t]{7}{*}{$\begin{array}{l}\text { Students' } \\
\text { personality }\end{array}$} & 1. Students as resisters & $0 \%$ & $0 \%$ & $60 \%$ & $40 \%$ & $100 \%$ \\
\hline & 2. Students as receptacles & $20 \%$ & $0 \%$ & $40 \%$ & $40 \%$ & $100 \%$ \\
\hline & 3. Students as raw material & $20 \%$ & $0 \%$ & $40 \%$ & $40 \%$ & $100 \%$ \\
\hline & 4. Students as clients & $0 \%$ & $20 \%$ & $60 \%$ & $20 \%$ & $100 \%$ \\
\hline & 5. Students as partners & $0 \%$ & $20 \%$ & $80 \%$ & $0 \%$ & $100 \%$ \\
\hline & 6. Students as individual explores & $0 \%$ & $60 \%$ & $40 \%$ & $0 \%$ & $100 \%$ \\
\hline & 7. Students as democratic explores & $0 \%$ & $40 \%$ & $60 \%$ & $0 \%$ & $100 \%$ \\
\hline \multirow[t]{2}{*}{$\begin{array}{l}\text { Students' } \\
\text { Motivation }\end{array}$} & 1. Intrinsic & $0 \%$ & $0 \%$ & $60 \%$ & $40 \%$ & $100 \%$ \\
\hline & 2. Extrinsic & $0 \%$ & $0 \%$ & $60 \%$ & $40 \%$ & $100 \%$ \\
\hline \multirow[t]{4}{*}{$\begin{array}{l}\text { Students' le } \\
\text { style }\end{array}$} & 1. Concrete learning style & $0 \%$ & $0 \%$ & $80 \%$ & $20 \%$ & $100 \%$ \\
\hline & 2. Analytical learning style & $0 \%$ & $40 \%$ & $60 \%$ & $0 \%$ & $100 \%$ \\
\hline & 3. Communicative learning style & $0 \%$ & $0 \%$ & $100 \%$ & $0 \%$ & $100 \%$ \\
\hline & 4. Authority-oriented learning style & $0 \%$ & $0 \%$ & $60 \%$ & $40 \%$ & $100 \%$ \\
\hline
\end{tabular}

$\mathrm{SD}=$ Strongly Disagree, $\mathrm{D}=$ Disagree, $\mathrm{A}=$ Agree, $\mathrm{SA}=$ Strongly Agree

She is a teacher who talkatively engages the students participation (Sercu, Bandura, Castro, Davcheva, Laskaridou,
Lundgren, García, and Ryan, 2005), and who is soft - hearted (Ferris and Hedgcock, 2005). During the class she has some 
discussion with small group students, and looks sociable showed on her facial expression that provides information about people temperament and personality (Ekman and Sejnowski, 1992). She is an enjoyable teacher who tries to facilitate a supportive learning environment (Felicia, 2012). The interaction with the English teacher believed by students is something enjoyable, it lades a positive persuasion which correct and change the students' attitude (Briñol, Tormala, Rucker, and Petty, 2004). In this eighth grades, they like both English language and the teacher thus they can create a cooperative work during the class, they are motivated to have good action and attitude even more participated to the classroom learning activity.

As similar as students' belief that affects their motivation in learning, the teacher's belief also affects her decision in teaching English. The teacher's belief about her classroom interaction is as students need facilitating media. Students' needs are met from students' differences information that are the students' different learning style (Felder and Brent, 2005), personality and motivation (Lubart, 2004). The teaching technique used was think pair share which is an effective warming up for the class discussion (Barkley, Cross, and Major, 2005), purposefully enable them interact verbally in realistic way (Peace Corps, 1989), and meet the students' communicative learning style. There is no intention to avoid another students' learning style, but the communicative is the dominant style believed by the teacher. The teacher decision to adjust their teaching style upon the students learning style is argued by Allwright and Bailey (1990) in Shomoossi (2004) as an important thing. The quality of personal relation (Schulte-Pelkum, Schweer, and Pollak, 2014), which can be the environmental aspect affecting the students motivation, become the teacher consideration to build an enjoyable learning activity, and make the students want to get involved to (Ames, 1990).

\section{CONCLUSIONS AND SUGGESTIONS}

Based on the research findings and discussion there are several conclusions formed. First, students' positive belief delivers positive attitude in the classroom and supports the presence of well-run and cooperatively high interaction. Although factors influenced more than one but the teacher's personality has big proportion in the students' belief. They would have the same proportion if the point of teacher's teaching style from students' belief is clear but the fact students express their idea about the teacher's personality clearer than another. Students believe that their teacher is less emotional, full of interact, care, enjoyable, and organized. This belief leads them to enjoy the classroom learning process, and English doesn't become a specter anymore for the students.

Second, the English teaching process delivered is influenced by the teacher's belief formed by the involvement of the students' variety. The teacher believes that classroom interaction is the students' need facilitating media. Believing that her students are motivated creature and $100 \%$ learning through communicative activity, the teacher formulates her way of teaching appropriately and plays role as team member, facilitator, group organizer, and quality controller to engage the students' activeness and maximize the students learning. She socially interacts with the students in order they enjoy the activity and feel comfortable. 
Third, students' and teacher's belief can affect the English teaching and learning process through creating mind conception. When people's mind creates a concept that something is the true one, every their action will be oriented to this mind conception. What they have seen in the classroom which then convinced as the truth becomes their rule to behave. The English teaching and learning process observed is not showing something chaotic because a cooperative interaction has supported the building of students' and teacher's positive belief mutually then has impacted the continuing process of teaching and learning English.

Considering the findings of this research, it is suggested that a teacher or teacher aspirant should have positive belief, before or when teaching. They can create or invest in their belief: (1) that teaching is a process of helping the students' learning, by guiding and working together, (2) that their

\section{BIBLIOGRAPHY}

Adams, Anne., \& Cox, Anna L. (2008). Questionnaires, in-depth interviews and focus groups. In: Cairns, Paul and Cox, Anna L. eds. Research Methods for Human Computer Interaction. Cambridge, UK: Cambridge University Press, pp. 1734. Retrieved from http://oro.open.ac.uk/11909/3/97805 21870122c02_p17-34.pdf

Ames, Carole A.(1990). Motivation: What Teachers Need to Know. Teachers Colledge Record, 91(3). Retreived From http://www.unco.edu/cebs /psychology/kevinpugh/motivation_ project /resources/ames90.pdf students are part of their family or community so they can be more interacted, open ended, and trusted each other, or any other things that can lead them to have positive belief. With this belief, they will have strong stand for their every action in teaching and they will be able to do something that might be impossible for them previously, like understand the students' psychological phase and make an interactive communication. The impact of this positive belief is not only felt by the teacher but also the students indeed this belief will affect the students to have the same positive belief. It is a good opportunity to create the students' belief that their teacher is not someone redoubtable so the students are confident enough to take part in the teaching learning process, and their enthusiasm or curiosity will be increased. This is a profitable situation, and teacher has an important role on it.

Ballone, Lena M., \& Czerniak, Charlene.(2001). Teachers' Beliefs about Accommodating Students' Learning Styles in Science Classes. Electronic Journal of Science Education, 6(2). Retrieved from http://wolfweb.unr.edu/homepage/cr owther/ejse/ balloneetal.pdf

Barkley, Elizabeth F., Cross, K. Partricia., \& Major, Claire Howell.(2005). Collaborative Learning Tecniques. San Francisco: Jossey Bass.

Bolkan, San.,Goodboy, Alan K., \& Griffin, Darrin J. (2013). Teacher Leadership and Intellectual Stimulation: Improving Students' Approaches to Studying through Intrinsic Motivation. Communication Research Report, 28(4), pp. 337-346. 
Retrieved

from

http://www.oswego.edu/Documents/ celt/Teacher\%20leadership\%20and $\% 20$ intellectual\%20stimulation $\% 20$ $\% 20$ improving\%20students $\% 27$ $\% 20$ approaches\%20to\%20studying $\% 20$ through $\% 20$ intrinsic $\% 20$ motivation.pdf

Briñol, Pablo, Petty, Richard E., \& Tormala, Zakary L. (2006). The Malleable Meaning of Subjective Ease. Association for Psychological Science, 17(3). Retrieved from https://www.google.co.id/url?sa=t\&r $\mathrm{ct}=\mathrm{j} \& \mathrm{q}=\&$ esrc $=$ s $\&$ source $=$ web $\& c d=7 \&$ cad $=$ rja $\&$ uact $=8 \&$ ved $=0$ CFIQFjAG\&url $=\mathrm{htt}$ p\%3A\%2F\%2Fwww.researchgate.ne t\%2Fprofile\%2FRichard_Petty\%2Fp ublication

Broughton, Geoffrey., Brumfit, Christopeher., Flavell, Roger., Hill, Peter., \& Pincas, Anita. (2003). Teaching Englishas a Foreign Language. Retrieved from http://elibrary.kiu.ac.ug:8080/jspui/bi tstream/1/269/1/

Teaching\%20English $\% 20$ as $\% 20 a \% 2$ 0Foreign\%20Language \%20(Routled ge\%20Education\%20Books).pdf

Burleson, Brant R. (2008). What Counts as Effective Emotional Support? Retrieved from http://www.sagepub.in/upmdata/21141_Chapter_10.pdf

Cuban, Larry. 2009. Hugging the MiddleHow Teachers Teach in an Era of Testing and Accountability. Retrieved from http://en.bookfi.org

Dimić, JasminaVrkić. (2012). Learning and Role of the Family in New Media Environment. World Journal of Education, 2(2). Retrieved from http://www.sciedu.ca/journal /index.php/wje/article/viewFile/994/ 507

Ekman, Paul., Huang, Thomas S., Sejnowski, Terrence J., \& Hager, Joseph C. (1992). Final Report To NSF of the Planning Workshop on Facial Expression Understanding Retrieved fromhttp://citeseerx.ist.psu. edu/viewdoc/download?doi=10.1.1.1 $64.1438 \&$ rep=rep1\&type $=$ pdf

Felder, Richard M., \& Brent, Rebecca. (2005) Understanding Student Differences. Journal of Engineering Education, 94(1),57-72. Retreived from http://www4.ncsu.edu /unity/lockers/users/f/felder/public/P apers

/Understanding_Differences.pdf

Felicia, Agbagbla. (2012). The Role of Nonverbal Communication in Preschool Classroom Interactions. Retrieved from https://www.hioa.no/content /download/25002/319347/ file/Felicia\%202.pdf

Ferris, Dana R.., \& Hedgcock, John S. (2005). Teaching English ESL Composition: Purpose, Process, and Practice. Retrieved from http://wpacouncil.org/archives/30n12/30n1-2-ortmeier-hooper.pdf

Graf, Sabine., Lin, Taitu., \& Kinshuk. (2002). Improving Student Modeling: The Relationship Between Learning Styles And Cognitive Traits. Retrieved from http://wit.at/people/graf/slides/CELD A05_FP_pres_final.pdf 
Graf, Sabine., Lin, Taiyu., Jeffrey, Lynn., \& Kinshu. (2002). An Exploratory Study of the Relationship between Learning Styles and Cognitive Traits. Retrieved from http://sgraf.athabascau.ca/publication s/

graf_lin_jeffrey_kinshuk_ECTEL06. pdf

Gunawan, Adi W. (2008). The Secret of Mindset. Jakarta: PT Gramedia Pustaka.

Huber, Franz. (2006). Belief and Degrees of Belief. Retrieved from http://www.hss.caltech.edu/ franz/C altech/PDFs/Franz\%20Huber\%20$\%$ 20Belief\%20and\%20Degrees $\% 20$ of $\% 20$ Belief $\% 20-\% 20$ DRAFT .pdf

Konsik, C., Beck, C., Freese, A. R., \& Samaras, A.P. (2005). Making a Difference in Teacher Education Trhough Self-Study. Retrieved from http://en.bookfi.org/s/?q=teacher\%27 $\mathrm{s}+$ personality $\& \mathrm{t}=0$

Lubart, Todd. (2004). Individual Student Differences and Creativity for Quality Education. Retrieved from http://unesdoc.unesco.org/images/ 0014/001466/146667e.pdf

Mackay, Jenny. (2006). Coat of Many Pockets: Managing Classroom Interactions. Retrieved from http://en.bookfi.org

Merriam, Sharan B. (1998). Case Studies as Qualitative Research. Retrieved from

http://www.appstate.edu/ jacksonay/ rcoe/merriam.pdf

Moleong, Lexy J. (2006). Metodologi Penelitian Kualitatif. Bandung: PT. Remaja Rosdakarya.
New South Wales Department for Education and Training. (2004). English as a Second Language. Retrieved from https://www.det.nsw.edu.au /policies/curriculum/schools /esl_guide/pd04_23_ESL_Guideline s.pdf

Peace Corps. (1989). TEFL/TESL: Teaching English as a Foreign or Second Language. Retrieved from http://www.edu.ro/index.php?modul e $\quad=$ uploads $\&$ func $=$ download \&fileId $=18401$

Pishghadam, Reza. (2011). Iranian PhD Students' Beliefs about Language Learning and Teaching: A Qualitative Study. World Journal of Education, 1(1), 63 - 71. doi:10.5430/wje.v1n1p63. Retrieved from

http://www.researchgate.net/profile/ Reza_Pishghadam/publication /228489335_Iranian_PhD_Students' _Beliefs_about_Language_Learning _and_Teaching_A_Qualitative_Stud y/links/0c9605368ec289a2c3000000. pdf

Richard, Jack C., \& Lockhart, Charles. (2007). Reflective Teaching in Second Language Classrooms. Retrieved from http://en.bookfi.org

Schmidt, Richard., Boraie, Deena., \& Kassabgy, Omneya. (1996). Foreign language motivation: Internal structure and external connections. In Rebecca Oxford (Ed.), Language Learning Motivation: Pathways to the New Century. (Technical Report \#11) (pp. 9-70). Retreived from http://nflrc.hawaii.edu/PDFs/SCHMI DT\%20Foreign\%20language\% 20motivation.pdf 
Schulte-Pelkum, Jörg.Schweer, Martin K.W., \& Pollak, Beate. (2014). Dyadic trust relationsbetween teachers and students - an empirical study about conditions and effects of perceived trustworthiness in the classroom from a differential perspective. Retrieved from http://www.uni-

vechta.de/fileadmin/user_upload/Pae dagogische

Psychologie/Dateien_Anrisse/201403-01_Sh9_Forschung_02_SchultePelkum_et_al.pdf

Sercu, Lies., Bandura, Ewa., Castro, Paloma., Davcheva, Leah., Laskaridou, Chryssa., Lundgren, Ulla., García, María del Carmen Méndez., and Ryan, Phyllis. (2005). Foreign Language Teachers and Intercultural Competence: An International Investigation. In Byram, Michael., and Phipps, Alison (Ed.), Languages For Intercultural Communication and Education. Retrieved from https://books.google.co.id/books?id= MHO0njbSdDcC\&pg=PR2\&lpg=PR $2 \& d q=$ Foreign + Language + Teachers + and+Intercultural+Competence: $+\mathrm{A}$ n+International+Investigation $+\mathrm{In}+\mathrm{B}$ yram,+Michael.,+and+Phipps,+Aliso $\mathrm{n}+\% 28 \mathrm{Ed} . \% 29,+$ Languages + For + Int ercultural+Communication+and+Ed ucation \&source $=$ bl\&ots $=$ JJSltmin 30 $\&$ sig=TF36ODa4c2ieZscRBoLmlJT $\mathrm{HjkM} \& \mathrm{hl}=\mathrm{en} \& \mathrm{sa}=\mathrm{X} \& \mathrm{ei}=-$ e9VVbuDC462uATF1IHACw\&ved

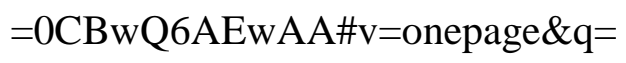
Foreign \%20Language\%20Teachers $\% 20$ and $\% 20$ Intercultural\%20Compe tence $\% 3 \mathrm{~A} \% 20 \mathrm{An} \% 20$ International $\% 20$ Investigation $\% 20 \mathrm{In} \% 20 \mathrm{Byram}$ $\% 2 \mathrm{C} \% 20 \mathrm{Michael} \% 2 \mathrm{C} \% 20$ and $\% 20$
Phipps\%2C\%20Alison\%20(Ed.)\%2 C\%20Languages\%20For\%20Intercu ltural $\% 20$ Communication $\% 20$ and $\%$ 20Education $\& \mathrm{f}=$ false

Shomoossi, Nematullah. (2004). The Effect of Teachers' Questioning Behavior on EFL Classroom Interaction: A Classroom Research Study. The Reading Matrix, 4(2). Retrieved from http://www.readingmatrix.com/articl es/shomoossi/article.pdf

Thomason, Amy C. (2011). Teacher Personal and Professional Characteristics: Contribution to Emotional Support and Behavior Guidance in Early Childhood Classrooms. Retrieved from http://libres.uncg.edu/ir/uncg/f/Thom ason_uncg_0154D_10586.pdf

Vosniadou, Stella. (2001). How Children Learn. http://unesdoc.unesco.org /images/0012/001254/125456e.pdf

Walker, J.M.T., \& Schussler, D.L. (2011). Journal of Classroom Interaction, 46(1), 3, ISSN 0749-4025 Retrieved from

http://www.academia.edu/971840/Te acher_Control_and_Affiliation_Do_ Students_and_Teachers_Agree

William, Marion.,\& Burden, Robert L. (1997). Psychology for Language Teachers. United Kingdom: Cambridge University Press.

Yin, Robert K. (2011). Qualitative Research from Start to Finish. Retrieved from http://en.bookfi.org 